\title{
Venovenosus extrakorporális
} membránoxigenizációval (ECMO) végzett mellkassebészeti mütétek tapasztalatai Magyarországon

\author{
Retrospektív klinikai tanulmány
}

\author{
Madurka Ildikó dr. ${ }^{1}$. Elek Jenő dr. ${ }^{1}$ - Kocsis Ákos dr. ${ }^{2}$ \\ Agócs László dr. ${ }^{2}$ - Rényi-Vámos Ferenc dr. ${ }^{2}$ \\ ${ }^{1}$ Országos Onkológiai Intézet, Aneszteziológiai és Központi Intenzív Terápiás Osztály, Budapest \\ ${ }^{2}$ Országos Onkológiai Intézet, Daganatsebészeti Központ, Mellkassebészeti Osztály, Budapest
}

\begin{abstract}
Bevezetés: A modern mellkassebészeti mútétek nagy része féloldali tüdőlélegeztetéssel és az operált oldal nyugalomba helyezésével történik úgy, hogy a sebészi feltárás és a beteg oxigenizációja egyaránt megfelelő legyen. A beavatkozás technikai korlátja, ha az intraoperatív gázcsere nem biztosítható: nincs elérhető légút, vagy nincsen elegendő gázcserét biztosító tüdőparenchyma. A lélegeztetés alternatíváját kezdetben a cardiopulmonalis bypass jelentette, napjainkban az extrakorporális membránoxigenizáció (ECMO) használata került előtérbe.

Célkitüzés: Az elektív, intraoperatív, venovenosus (VV-) ECMO-val végzett mellkassebészeti mütéteink indikációinak, biztonságosságának, a perioperatív morbiditásra és mortalitásra gyakorolt hatásának retrospektív vizsgálata.

Betegek és módszer: A 2014. 04. 28. és a 2018. 04. 30. közötti időszakra vonatkozóan az Országos Onkológiai Intézet számítógépes adatbázisából megállapítottuk, hogy 12 beteg mútéténél használtunk intraoperatív VV-ECMO-t.

Eredmények: A betegek átlagéletkora 45 év volt, alapbetegségük 2 esetben benignus, 10 esetben malignus daganat. Az ECMO indikációját 3 esetben extrém súlyos légcsőszúkület jelentette, 4 betegnél korábbi tüdőreszekció miatt az intraoperatív gázcseréhez elégtelen tüdőállomány. 5 beteg esetében mind a légút, mind a parenchyma hiánya képezte az ECMO indikációját. Az apnoe (átlagosan 142 perc) megszakítására nem volt szükség. A VV-ECMO-kezeléssel összefüggő szövődményt nem észleltünk. Intraoperatív halálozás nem történt, a 30 napos perioperatív halálozás $8,33 \%$ volt.

Következtetés: Technikai inoperabilitás esetén, ha nincs az intraoperatív lélegeztetéshez használható légút, vagy nem áll rendelkezésre elegendő tüdőparenchyma a gázcseréhez, és a kis vérköri vérkeringés fenntartásához elegendő a pulmonalis érmeder, valamint nincs szülkség a nagyerek reszekciójára, a VV-ECMO biztonságosan, a vérzésveszély fokozódása nélkül, több órán keresztül pótolja a teljes pulmonalis gázcserefunkciót. A VV-ECMO alkalmazása nem növelte a perioperatív morbiditást és mortalitást. A VV-ECMO alkalmazásával inoperábilis betegek válnak operálhatóvá.
\end{abstract}

Orv Hetil. 2019; 160(42): 1655-1662.

Kulcsszavak: venovenosus ECMO, mellkassebészet, inoperabilitás, extrakorporális membránoxigenizáció, apnoe

\section{Experiences with venovenous extracorporeal membrane oxygenation (ECMO) support for thoracic surgery in Hungary}

\section{Retrospective clinical study}

Introduction: Most modern thoracic operations are performed with single-lung ventilation balancing between convenient surgical approach and adequate gas exchange. The technical limitations include difficult airways or insufficient parenchyma for the intraoperative single-lung ventilation. Earlier, cardiopulmonary bypass was the only solution, however, today the extracorporeal membrane oxygenation is in the forefront. 
Aim: We retrospectively analysed our elective operations by use of venovenous ECMO to assess the indication, safety, perioperative morbidity and mortality.

Patients and method: 12 patients were operated using venovenous (VV-) ECMO between 28 April 2014 and 30 April 2018 in the National Institute of Oncology. The main clinicopathological characteristics, data regarding the operation, the use of ECMO and survival were collected.

Results: The mean age was 45 years, 2 patients had benign and 10 had malignant diseases. Extreme tracheal stricture was the indication for ECMO in 3 cases, while 4 patients had previous lung resection and lacked enough parenchyma for single-lung ventilation. 5 patients had both airway and parenchymal insufficiency. The average time of apnoea was 142 minutes without interruption in any of the cases. We did not experience any ECMO-related complication. We had no intraoperative death and 30-day mortality was $8.33 \%$.

Conclusion: In case of technical inoperability, when there is no airway or insufficient parenchyma for gas exchange, but pulmonary vascular bed is enough and there is no need for great-vessel resection, VV-ECMO can safely replace the complete gas exchange without further risk of bleeding. The use of VV-ECMO did not increase the perioperative morbidity and mortality. Previously inoperable patients can be operated with VV-ECMO.

Keywords: venovenous ECMO, thoracic surgery, inoperability, extracorporeal membrane oxygenation, apnoea

Madurka I, Elek J, Kocsis Á, Agócs L, Rényi-Vámos F. [Experiences with venovenous extracorporeal membrane oxygenation (ECMO) support for thoracic surgery in Hungary]. Orv Hetil. 2019; 160(42): 1655-1662.

(Beérkezett: 2019. május 15.; elfogadva: 2019. június 11.)

\section{Rövidítések}

ACC $=$ (adenoid cystic carcinoma) adenocysticus carcinoma; ACT $=$ (activated coagulation time) aktivált koagulációs idő; $\mathrm{AV}=$ arteriovenosus $; \mathrm{CO}=$ (cardiac output) szívperctérfogat; $\mathrm{CPB}=$ (cardiopulmonary bypass) cardiopulmonalis bypass; $\mathrm{ECMO}=($ extracorporeal membrane oxygenation $)$ extrakorporális membránoxigenizáció; FEVl = (forced vital capacity in 1 second) az első másodpercre eső erőltetett kilégzési térfogat; $\mathrm{Fr}=$ french, $0,33 \mathrm{~mm} ; \mathrm{IU}=$ (international unit $)$ nemzetközi egység; TIA = (transient ischaemic attack $)$ átmeneti agyi keringészavar; VA $=$ venoarteriosus; VATS $=($ video-assissted thoracoscopic surgery) videoasszisztált torakoszkópia; $\mathrm{VV}$ = venovenosus; VV-ECMO = (venovenosus extracorporeal membrane oxygenation) venovenosus extrakorporális membránoxigenizáció

A mellkassebészet fejlődését a technikai eljárások változása alapozta meg [1]. Az intubációs lélegeztetés lehetővé tette az izomrelaxánsok használatát és a mûtét alatti megfelelő ventilációt. A Carlens által 1949-ben kifejlesztett dupla lumenú tubus alkalmazása biztosította a két tüdőfél külön lélegeztetését és ezzel az operálandó tüdó nyugalomba helyezését [2]. A nagyfrekvenciás 'jet' ventiláció (JET) alkalmazása a speciális légúti sebészetben kapott szerepet $[3,4]$. Napjainkban a modern mellkassebészet alapjait a varrógépek bevezetése, a minimálinvazív módszer és a videotechnika biztosítja. A mellkasi mútétek nagy része a féloldal lélegeztetésével és az operált oldal nyugalomba helyezésével történik úgy, hogy a sebészi feltárás és a beteg oxigenizációja egyaránt megfeleló legyen. A mellkassebészeti beavatkozások technikai korlátja, ha az intraoperatív gázcsere nem biztosítható. Lélegeztethetetlenség áll fenn, ha nincs elérhetô légút (extrém súlyos légcsőszúküulet), vagy ez utóbbi folytonossága a mútéti technika révén megszúnik. Nem biztosítható az oxigenizáció akkor sem, ha a beavatkozás alatt nincsen elegendő tüdő́állomány. Egyes esetekben megoldás lehet a kontrollált apnoe alkalmazása, a JET ventiláció vagy belső intubáció, a 'cross-table' technika. Kevés tüdőparenchyma esetén segíthet az operált oldal insufflatiója vagy részleges lélegeztetése [5]. Ezekben az esetekben különösen fontos az operatőr és az aneszteziológus teljes kooperációja, összhangja a váratlan szövődmények (vérzés, légútvesztés, tüdőödéma) elhárításához [6]. A lélegeztetés alternatíváját kezdetben a cardiopulmonalis bypass (CPB) alkalmazása jelentette. Míg az első sikeres szívmútétet szív-tüdő motoron John Gibbon már 1953ban elvégezte [7], addig az elsô mellkassebészeti alkalmazásáról Woods és mtsai csak 1961-ben számoltak be, amelynek során extrakorporális keringésben a distalis tracheából kiinduló adenocysticus carcinomát (ACC) sikeresen reszekáltak [8]. A CPB-nek elónyei mellett a hátrányait is leírták, például a teljes véralvadásgátlás következményeként fellépő transzfúziós igényt, valamint a szívók miatti tumorsejtszóródás lehetőségét $[9,10]$. Reális alternatívát jelentett a venoarteriosus (VA-) [11], majd a venovenosus extrakorporális membránoxigenizáció (VV-ECMO) használata [12]. Kezdetben ECMO-t gyerekek komplex veleszületett légcsőfejlődési rendellenességének rekonstrukciójakor használtak [13]. Az újszülöttek mútétei során szerzett pozitív tapasztalatok alapján (az operálandó terület jobb feltárása intratrachealis tubus és idôszakos agresszív lélegeztetés nélkül) az ECMO használata a felnőttek mellkassebészetében is előtérbe került. Az orvostechnikai fejlődésnek köszönhetően, valamint a 2009. évi HINl-járvány kapcsán az ECMO használata ugrásszerúen elterjedt [14, 15], és a szívsebészeten kívül az általános intenzív osztályokon 


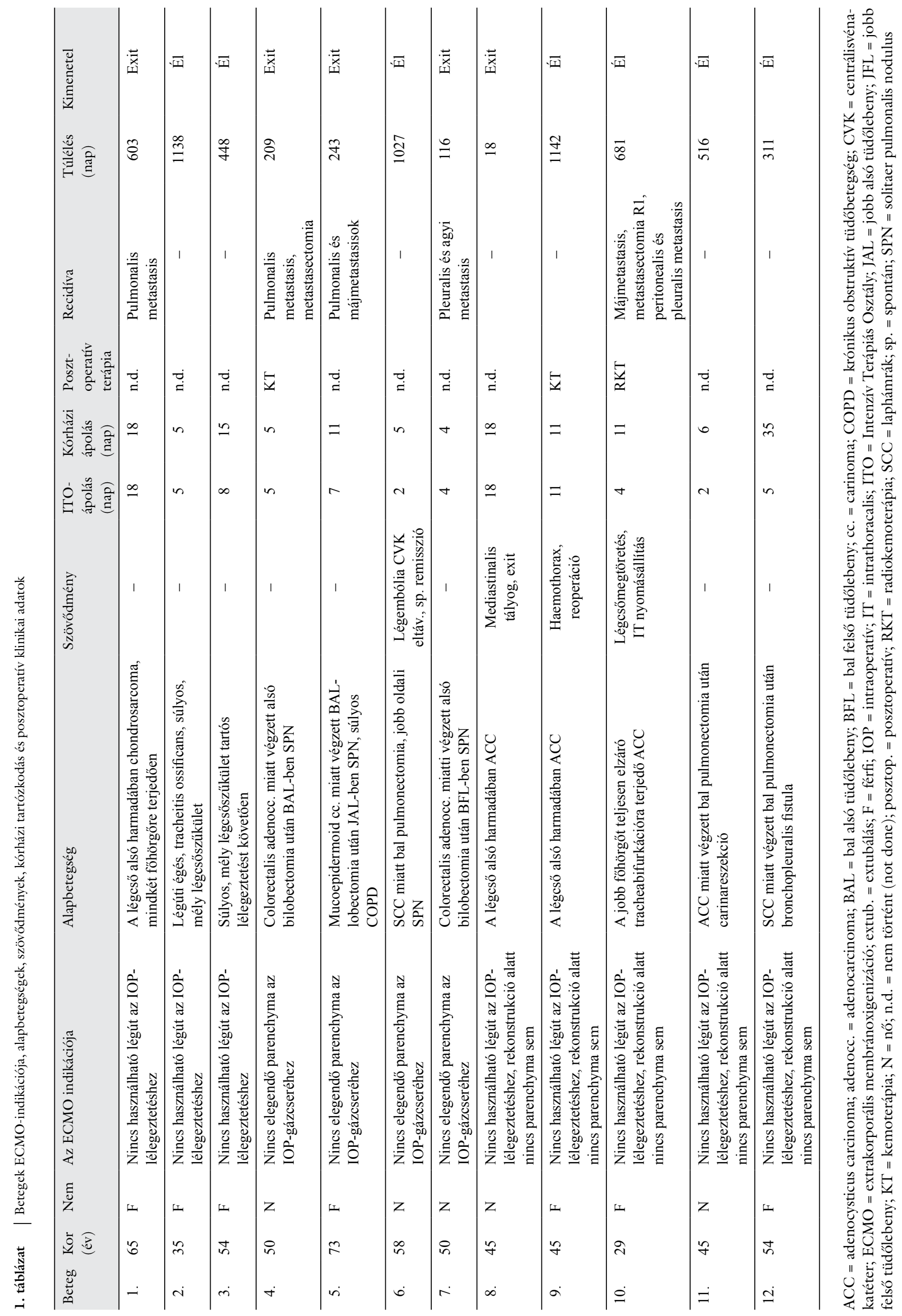




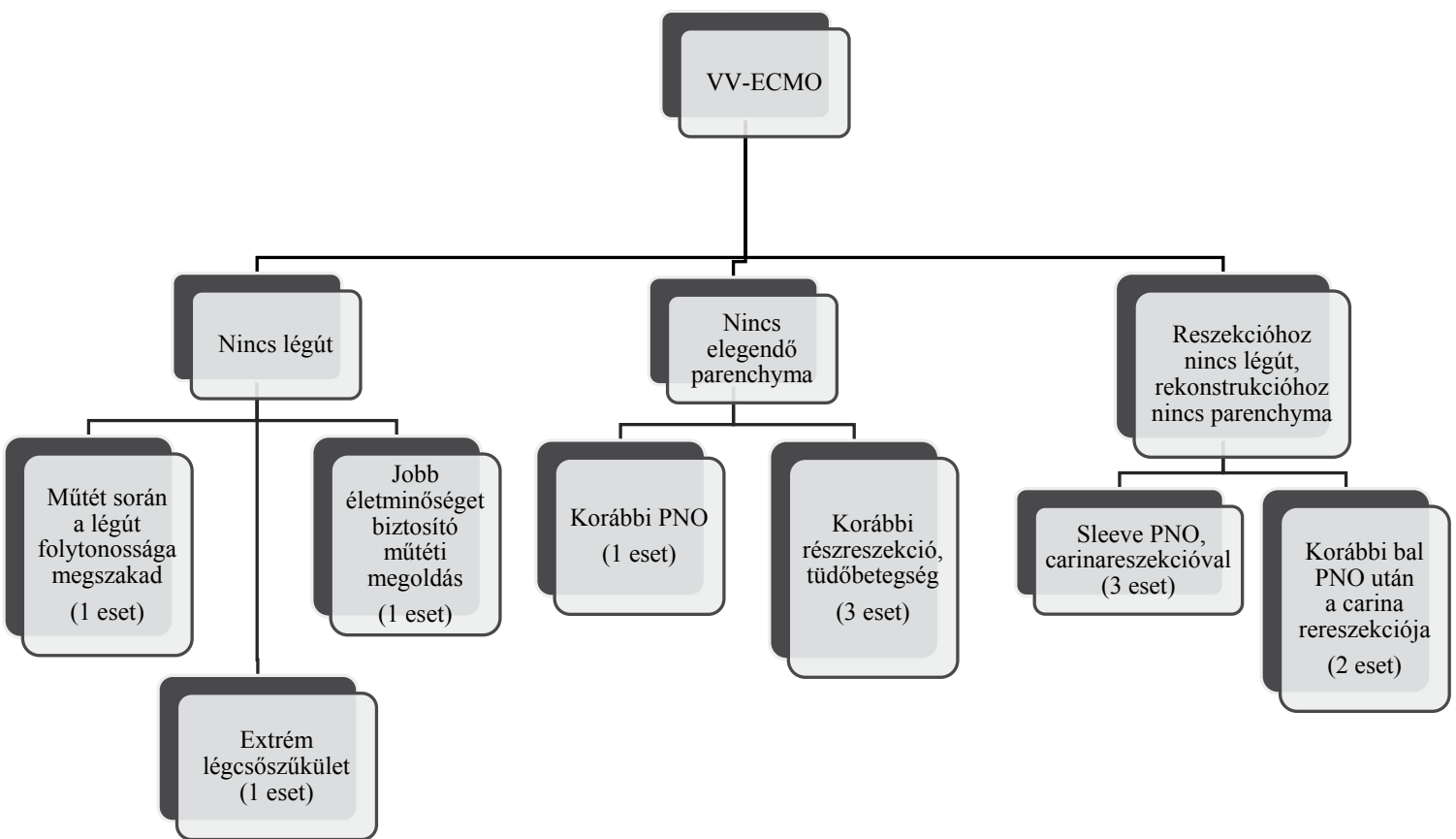

1. ábra

A VV-ECMO indikációja a vizsgált betegeknél

$\mathrm{PNO}=$ pulmonectomia $; \mathrm{VV}-\mathrm{ECMO}=$ venovenosus extrakorporális membránoxigenizáció

egyre gyakrabban alkalmazták. Az első venovenosus perkután CPB-használatról 1997-ben Horita számolt be [16], aki két sikeres carinareszekciót, majd -rekonstrukciót végzett. Az eset leírásából válik világossá, hogy valójában a szív-tüdő motor elemei közül csak a pumpát és az oxigenátort használta fel, a rezervoárt nem, míg a kanülöket perkután Seldinger-technikával a vena (v.) femoralisokon keresztül a jobb pitvarba, illetve a v. cava inferiorba vezette. A mai nevezéktan szerint femorofemoralis VV-ECMO-t valósított meg. Azóta szórványos esetleírásokat közöltek extrakorporális keringéstámogató eszközök használatáról nagy légúti sebészetben $[17,18]$ és a tüdőparenchyma-elégtelenséggel járó mütétek kapcsán [19-21].

\section{Célkitüzés}

Dolgozatunk célja az elektív, intraoperatív VV-ECMOval végzett mellkassebészeti mútéteink retrospektív vizsgálata, különös tekintettel az indikációra, a módszer biztonságosságára, a perioperatív morbiditásra és mortalitásra.

\section{Betegek és módszer}

A 2014. 04. 28. és 2018. 04. 30. közötti időszakra vonatkozóan az Országos Onkológiai Intézet számítógépes adatbázisából retrospektív adatgyưjtés során megállapítottuk, hogy 12 beteg mútéténél használtunk intraoperatív VV-ECMO-t. Vizsgálatunkat a Semmelweis Egyetem Regionális Kutatásetikai Bizottsága a SE-
RKEB 13/2019-es számmal engedélyezte. A klinikai adatokat anonim módon SPSS-táblázatban rögzítettük. A betegeket 2018. 12. 31-ig követtük. A klinikai adatokat, az alapbetegségeket, a mütéti és ECMO-indikációkat, a szövődményeket és a betegek követését az 1 . táblázatban és az 1. ábrán foglaltuk össze. A 7 férfi és 5 nőbeteg átlagéletkora 45 év (29-73) volt. Alapbetegségük 2 esetben benignus, 10 esetben malignus daganat (chondrosarcoma [1], adenocysticus carcinoma [4], laphámrák [2], mucoepidermoid carcinoma [1] és metastasis [2]) volt. Az ECMO indikációját 3 esetben képezte extrém súlyos légcsőszúlkület. Az 1 . betegnél (2. és 3 . ábra) az intraoperatív lélegeztetéshez szükséges biztos légút hiányán túl a károsodott parenchyma sem tette volna lehetővé az intraoperatív féloldali gázcserét. Az 1-3. betegnek olyan súlyos légcsőszúkülete volt, amely kivitelezhetetlenné tette az intubációt. Az 1. és 2. betegnél az ECMO bevezetése ezért éber állapotban történt, és a betegeket kellő ECMO-áramlás elérése után altattuk el. A 3. számmal jelölt, posztintubációs légcsőszúkület esetében a pácienst tracheostomás kanülön lélegeztettük a sebészi explorációig. A feltárást követően a kedvezőtlen anatómiai szituáció (mély tracheostoma, rövid nyak, heges szövetek, a mútéti feltárást zavaró tracheostomás kanül) és a fokozott rizikót jelentő sternotomia elkerülése céljából az operatőrrel egyeztetve döntöttünk ECMO használata mellett. A 4-7. esetnél korábbi tüdőreszekció miatt nem állt rendelkezésre mütét alatt elegendő gázcserét biztosító parenchyma. 3 beteg esetében részreszekció (FEVl: 45-56\%), egyben pedig pulmonectomia volt a megelőző tüdőmütét (FEVl: 56,7\%). A 8-10. 


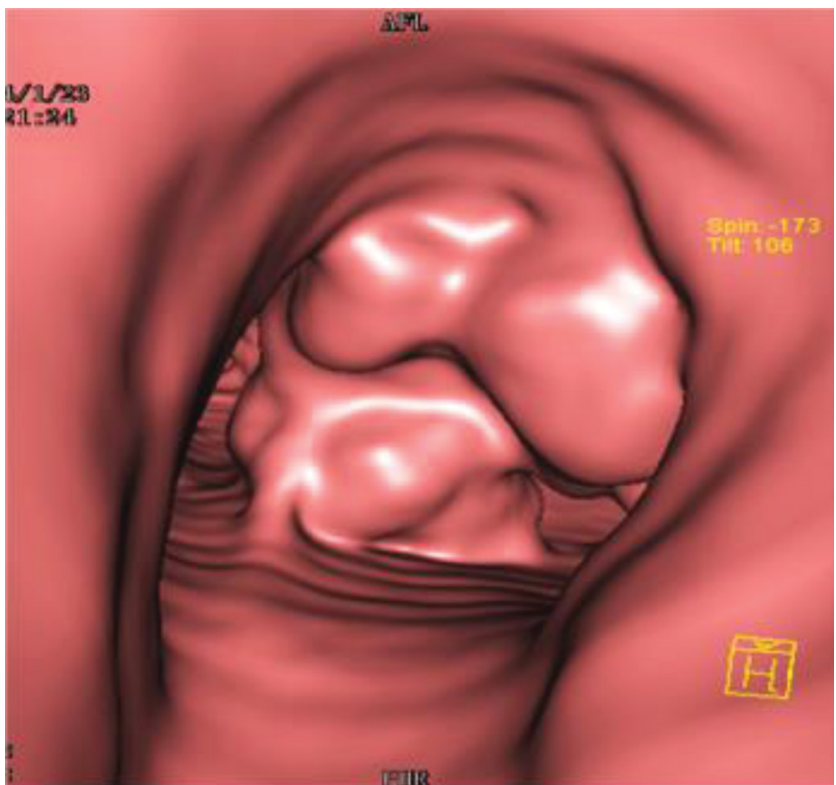

2. ábra

A carinából kiinduló chondrosarcoma, mely csaknem teljes elzáródást okoz

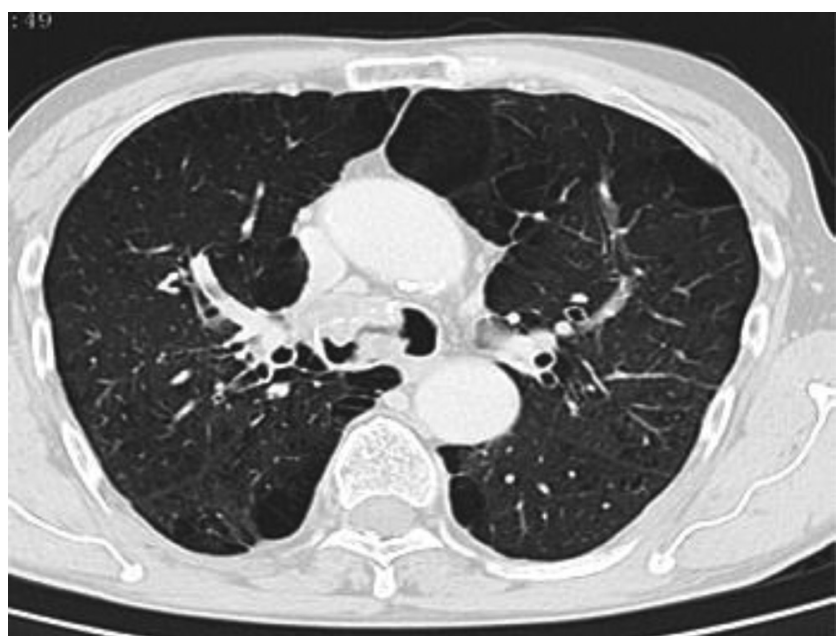

3. ábra

A szinte teljes elzáródást okozó carinatumor mellett a parenchyma is károsodott

esetben bifurkációra terjedő malignitás miatt pulmonectomiát követően komplex tracheobronchialis reszekciót végeztünk. A 11 . és 12. eset is hasonló mütétet indikált, azzal a különbséggel, hogy a pulmonectomiát egy korábbi beavatkozás során végezték el, a carinarereszekció a második ülésben történt, egy esetben onkológiai indikációval (11. beteg), egyben pedig hörgőcsonk-elégtelenség miatt (12. beteg). Ez utóbbi esetben az ECMOkanülálást éber betegen végeztük, a beteget a mütét alatt sem intubáltuk. Posztoperatív 48 óráig prolongált ECMO-kezelést folytattunk a kielégítő oxigenizáció eléréséhez. Ez az idő elég volt ahhoz, hogy a hörgőcsonkelégtelenség következtében kialakult jobb oldali infiltrátum jelentősen regrediáljon. A VV-ECMO-támogatást minden esetben perifériás, femorojugularis kanülálással végeztük, a kanülöket a mütőben az anesztezioló- gusok perkután vezették be. Az esetek többségében a jobb oldali femoralis és jugularis vénákat kanüláltuk, kétkét esetben ( 4 beteg) csak a bal oldali femoralis, illetve jugularis vénába tudtunk kanülöket vezetni. Minden kanül heparinbevonatos volt. A szívókanülök (venous HLS cannulae, BIOLINE-coated, Maquet, Getinge, Göteborg, Svédország) 19-25 Fr, 38 cm hosszúak, míg a visszaadó kanülök (arterial HLS cannulae, BIOLINEcoated, Maquet, Getinge) 15-21 Fr, 15, illetve $23 \mathrm{~cm}$ hosszúak voltak. Kanüláláshoz egyszeri 2-5000 NE (70 IU/ttkg) Na-heparint adtunk vénásan. A heparin hatását ágy melletti ACT-méréssel (Hemochron Signature Elite, ITC, San Francisco, CA, Amerikai Egyesült Államok) kontrolláltuk. 'Cell saver'-t (C.A.T.S ${ }^{\circledR p l u s}$, Continuous AutoTransfusion System, Fresenius Kabi, Bad Homburg vor der Höhe, Németország) csak benignus alapbetegség során használtunk. Minden esetben portábilis Cardiohelp System-et használtunk a szintén heparinbevonatos (BIOLINE-coated) HLS 7.0 Advanced (Maquet, Getinge) egybeépített cső- és oxigenátorrendszerrel és a rendszert $500-600 \mathrm{ml}$ izotóniás sóoldattal feltöltve. Az ECMO áramlását a becsült szívperctérfogathoz közeli értéken tartottuk (>CO 80\%-a). Amennyiben az ECMO-áramlás további növelése csak mechanikai sejtkárosodás kockázatával járó nagy szívóerő árán valósulhatott volna meg, a beteg szívperctérfogatát gyógyszerrel, kontrolláltan csökkentettük. Mind a 10, endotrachealisan intubált beteget a mútőben extubáltuk. Az ECMO-kezelés befejezését követően a kanülöket 11 esetben a mütőben távolítottuk el, és ezt követően 20 percen keresztül manuális kompressziót alkalmaztunk a szúrcsatornán, majd további 24 órára nyomókötéssel láttuk el.

\section{Eredmények}

2014. 04. 28. és 2018. 04. 30. között 12 beteg mütétjénél használtunk intraoperatív femorojugularis VV-ECMO-t. A betegek átlagosan 7,4 napot (2-18 nap) töltöttek el az intenzív osztályon, és az intézetet átlagosan 12 nap (4-35 nap) után hagyták el. Az első 5 beteg (1., 4., 5., 6., 11.) a teljes kórházi ellátását az intenzív osztályon töltötte. Eseteinkben mind a kanülálás, mind a VV-ECMO-kezelés szövődménymentes volt. Neurológiai szövődmény a közvetlen posztoperatív szakban sem volt. Egy esetben később, a posztoperatív 5. napon centrális vénakatéter eltávolításával összefüggésben jelentkező TIA hátterében légembóliát véleményeztünk. Reoperációra egy esetben került sor haemothorax miatt, melyet egy intercostalis véna lumenes vérzése okozott. Egy beteg esetében a 3. posztoperatív napon reintubáció, lélegeztetés vált szükségessé újonnan kialakuló infiltrátum miatt, majd a beteg progrediáló szepszis, sokszervi elégtelenség tünetei között a 18. posztoperatív napon exitált. További egy beteget kellett ismét átmenetileg intenzív osztályunkra áthelyezni. A nagyfokú légszomj hátterében a mediastinum operált oldalra történő áthú- 
2. táblázat | Mútéti adatok

\begin{tabular}{|c|c|c|c|c|c|c|c|c|c|c|c|}
\hline Beteg & $\begin{array}{l}\text { Kor } \\
\text { (év) }\end{array}$ & Nem & Mütét & $\begin{array}{l}\text { Mútéti } \\
\text { behatolás }\end{array}$ & $\begin{array}{l}\text { Kanülálási } \\
\text { idő (min) }\end{array}$ & $\begin{array}{l}\text { Heparin } \\
\text { (IU) }\end{array}$ & $\begin{array}{l}\text { ACT } \\
\max .(s)\end{array}$ & $\begin{array}{l}\text { VVT } \\
(\mathrm{ml})\end{array}$ & $\begin{array}{l}\text { ECMO- } \\
\text { áramlás } \\
\text { (l/min) }\end{array}$ & $\begin{array}{l}\text { ECMO- } \\
\text { idő ( } \mathrm{min})\end{array}$ & $\begin{array}{l}\text { Apnoe- } \\
\text { idő } \\
(\mathrm{min})\end{array}$ \\
\hline 1. & 65 & $\mathrm{~F}$ & Bifurkációreszekció, neocarina-képzés & Jobb PLT & 20 & 5000 & 540 & 800 & 3,4 & 455 & 198 \\
\hline 2. & 35 & F & $\begin{array}{l}\text { Tracheotomia, Montgomery-tubus- } \\
\text { behelyezés }\end{array}$ & $\begin{array}{l}\text { Nyaki } \\
\text { anterior }\end{array}$ & 55 & 3000 & 270 & - & 4 & 165 & 120 \\
\hline 3. & 54 & $\mathrm{~F}$ & Tracheareszekció & $\begin{array}{l}\text { Nyaki } \\
\text { anterior }\end{array}$ & 60 & 3000 & 158 & - & 4,14 & 252 & 195 \\
\hline 4. & 50 & $\mathrm{~N}$ & JFL-VATS-ékreszekció & Bal triport & 15 & 2000 & 115 & - & 2,4 & 55 & 25 \\
\hline 5. & 73 & F & JAL-VATS-lobectomia & Jobb triport & 80 & $\begin{array}{l}5000 \\
2000\end{array}$ & 352 & 600 & 2,8 & 240 & 100 \\
\hline 6. & 58 & $\mathrm{~N}$ & JFL-VATS-ékreszekció & Jobb triport & 25 & 5000 & 163 & - & 2,6 & 70 & 65 \\
\hline 7. & 50 & $\mathrm{~N}$ & BFL-VATS-ékreszekció & Bal triport & 95 & 5000 & 148 & 400 & 3,5 & 100 & 65 \\
\hline 8. & 45 & $\mathrm{~N}$ & $\begin{array}{l}\text { Bifurkációreszekció, bal oldali } \\
\text { pulmonectomia }\end{array}$ & $\begin{array}{l}\text { Bal és jobb } \\
\text { PLT }\end{array}$ & 50 & 4000 & 450 & 400 & 3,2 & 503 & 310 \\
\hline 9. & 45 & $\mathrm{~F}$ & $\begin{array}{l}\text { Bifurkációreszekció, bal oldali } \\
\text { pulmonectomia }\end{array}$ & $\begin{array}{l}\text { Bal és jobb } \\
\text { PLT }\end{array}$ & 75 & 4000 & 322 & 400 & 4,2 & 315 & 185 \\
\hline 10. & 29 & $\mathrm{~F}$ & $\begin{array}{l}\text { Bifurkációreszekció, jobb pulmonec- } \\
\text { tomia }\end{array}$ & Jobb PLT & 20 & 4000 & 196 & - & 5,6 & 245 & 150 \\
\hline 11. & 45 & $\mathrm{~N}$ & Bifurkációreszekció & Jobb PLT & 50 & 5000 & 202 & - & 4,6 & 151 & 135 \\
\hline 12. & 54 & $\mathrm{~F}$ & Rereszekció, bifurkációreszekcióval & Jobb PLT & 30 & 3000 & 172 & 400 & 4,99 & $\begin{array}{l}\text { Posztop. } \\
48 \text { óra }\end{array}$ & 130 \\
\hline
\end{tabular}

$\mathrm{ACT}=$ aktivált koagulációs idő; $\mathrm{BAL}=$ bal alsó tüdőlebeny; $\mathrm{BFL}=$ bal felső tüdőlebeny; $\mathrm{ECMO}=$ extrakorporális membránoxigenizáció; $\mathrm{F}=$ férfi; IU = nemzetközi egység; JAL = jobb alsó tüdőlebeny; JFL = jobb felső tüdőlebeny; $1=$ liter; $\min =$ perc; $\mathrm{ml}=$ milliliter; $\mathrm{N}=$ nő; $\mathrm{PLT}=$ posterolateralis thoracotomia; posztop. $=$ posztoperatív; $\mathrm{s}=$ másodperc; VATS $=$ videoasszisztált torakoszkópia; VVT $=$ vörösvértest

zottsága és ezáltal a légcső megtöretése állt, amelyet az operált oldal intrathoracalis nyomásának beállításával korrigáltunk. Intraoperatív halálozás nem fordult elő, a 30 napos perioperatív halálozás $8,33 \%$ volt $(8$.). Egy éven belül további 3 beteg hunyt el, kettő a malignus alapbetegség recidívája miatt $(4 ., 7$.), egy pedig cardiovascularis elégtelenségben (5.). A vizsgálati periódus végén a betegek $58,33 \%$-a élt annak ellenére, hogy többségük $(71,4 \%)$ malignus alapbetegségben szenvedett (4. ábra). A mútéti adatokat a 2. táblázat mutatja. A mútéteket 4 esetben jobb oldali posterolateralis, két esetben kettős thoracotomiából, két esetben elülső nyaki feltárásból végeztük. 3 esetben VATS-ékreszekció, egy esetben VATS-lobectomia történt. Az átlagos mútéti idő 232 perc volt (25-580), az átlagos VV-ECMO-idő 229 perc $(55-503,11$ beteg). Az átlagos apnoeidő, amikor a beteget nem lélegeztettük, és oxigenizációját csak a VV-ECMO biztosította, 142 perc volt (25-310). A behelyezett kanülök mérete minden esetben kielégítő, a becsült szívperctérfogathoz közeli ECMO-áramlást (2,4-5,6 1/min) biztosított, így a mútét elvégzéséhez szükséges idôt nem korlátozta. Az apnoe alatt a betegek oxigenizációja megfelelő volt, egyszer sem volt szükség az apnoe megszakítására, alternatív lélegeztetési módra (átmeneti insufflatio belső intubációval, oxigéninsufflatio, JET). Az első betegeknél még magasabb ACT-célér- tékekre törekedtünk, majd a továbbiakban csökkentettük, és az alacsonyabb ACT-beállítások eredményeképpen a műtétek transzfúziós igénye is számottevően csökkent. A második 6 betegból (2., 3., 8., 9., 10., 12.) csak két esetben volt szükség transzfúzióra, szemben az első 6 beteggel (1., 4., 5., 6., 7., 11.), akiknél 4 esetben jelentôsebb vérpótlás vált indokolttá. Thrombusképzőódést az alacsonyabb ACT-célérték mellett sem tapasztaltunk.

Túlélés (nap), exit Túlélés (nap), él

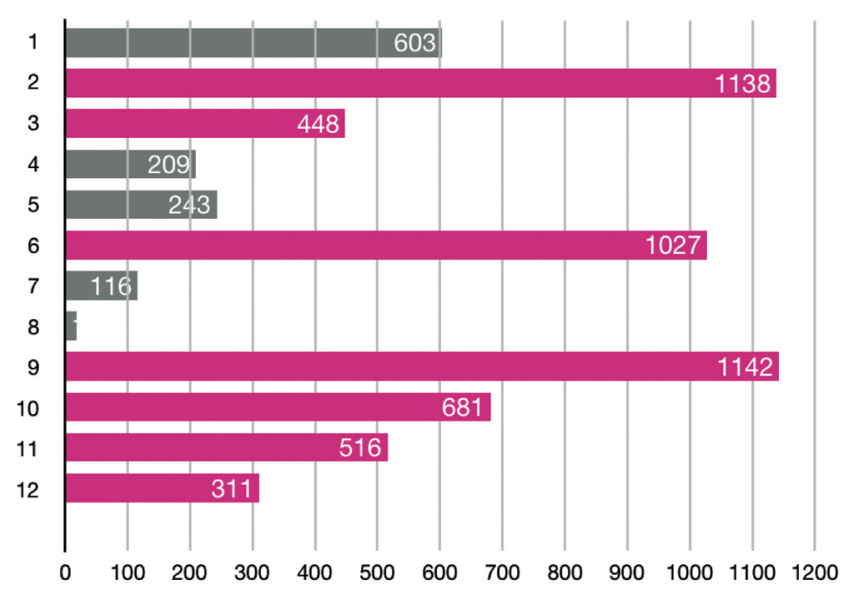

4. ábra $\mid$ A betegek túlélése 


\section{Megbeszélés}

A mellkassebészetben technikai inoperabilitást jelent, ha az onkológiailag indokolt és sebészileg operálható mütét az intraoperatív gázcsere lehetetlensége miatt nem végezhető el. Ezek okai: 1) a lélegeztetésre nem áll rendelkezésre használható légút; 2) a kielégítő gázcseréhez nem elegendő a tüdőállomány. A fenti mütéteket korábban szórványosan CPB mellett végezték. Wiebe és mtsai 10 év alatt 13 esetről számoltak be, becslésük szerint a mellkassebészeti beavatkozások $0,1 \%$-a történik szív-tüdő motorral [9]. A CPB alkalmazásának hátránya a teljes antikoaguláció miatti nagyobb intraoperatív vérigény, a tumorsejtek szóródásának lehetósége, a gyulladásos kaszkád aktiválódása. A CPB helyett a technika fejlődése a zárt rendszerü VA-ECMO használatát tette lehetővé, mellyel a fenti hátrányok csökkenthetők, kiküszöbölhetők [11]. Ha csak légzéstámogatásra van szükség, és nem történik a szívet, nagyereket érintő beavatkozás (aorta, pulmonalis törzs, v. cava), úgy a VV-ECMO alkalmazása reális alternatívát jelent.

A vizsgált periódus 48 hónapja alatt 12 beteg esetében, intraoperatív szakban, tervezetten alkalmaztuk az ECMO-támogatást. Valamennyi betegünknél VV-ECMO-val biztosítottuk a teljes gázcserét; mivel vascularis mütét nem történt, cardiopulmonalis bypassra nem volt szükség. VV-ECMO alkalmazásáról mellkassebészeti indikációval csak egy-egy eset kapcsán szórványosan számoltak be $[22,23]$. Franciaországban Rinieri és mtsai 42 hónap adatait dolgozták fel, és a mellkassebészeti centrumok tüdőtranszplantáción kívüli ECMOhasználatát vizsgálták [18]. Csak a centrumok felében, 17-ben, és összesen 36 esetben használtak ECMO-t, közülük 20 volt $\mathrm{VV}$-ECMO. A mútétek száma egyik centrumban sem haladta meg a hármat. Az indikációt fóleg a neoplasztikus eredet jelentette, de infekció, iatrogenia és trauma is szerepelt. Egy másik munkacsoport a németországi Ibbenbürenben 1 év alatt 9 betegnél végzett VVECMO-támogatással mellkassebészeti beavatkozást [24] 8 esetben malignitás miatt, és 1 esetben történt benignus betegség talaján volumenredukciós mútét. 6 esetben csak alacsony áramlású, szén-dioxid-eliminációt biztosító támogatás történt, és csak 3 esetben alkalmaztak globális gázcserét biztosító femorojugularis (pitvari) 'high-flow' VV-ECMO-t. Magunk a kanülálást perkután, Seldingertechnikával végeztük. Szövődményt sem a kanülök bevezetésekor, sem az ECMO-kezelés fenntartása alatt, sem a kanülök eltávolítása után nem észleltünk. A femorojugularis kanülpozíció különösen az egy combon végzett VA femoralis kanül pozíciójához képest kevésbé invazív, kisebb az esély a haematoma, az AV-fistula, a lymphacsorgás kialakulására. Ez utóbbiról fóleg a VA-ECMO-hoz alkalmazott sebészi feltárás kapcsán számoltak be [11]. $\mathrm{Az}$ artériás érpálya érintetlensége miatt a VV-ECMO során a kanülálás kevésbé szövődményes, a légembólia veszélye is kisebb. Éber állapotban kanülálást három esetben végeztünk, kettőben extrém súlyos légcsőszúkület miatt (1. beteg, 2. beteg). A harmadik esetben (12. beteg) a korábbi bal oldali pulmonectomiát követően kialakult bronchopleuralis fistula előre jelezte a lélegeztetés lehetetlenségét, a jobb oldali pneumonia pedig az elégtelen intra- és posztoperatív gázcserét. Intrathoracalis traumás légcsősérülés sürgős mütéte kapcsán intubáció nélküli, ébren bevezetett VV-ECMO alkalmazásáról egy közlés ismert [25]. Az átlagos apnoeidőnk (142 perc) meghaladta a Rinieri által leírt 78 percet [18]). A leghosszabb apnoeidőnk ( 310 perc) is hosszabb volt, mint az irodalomban olvasható, széles határok között megadott idők (40 perc [24], 48 perc [26], 209 perc [18]). Az általunk használt nagy kapacitású oxigenátorokkal a tüdő funkciójának teljes pótlását 5 órán túl is megszakítás nélkül tudtuk biztosítani, az apnoe hosszát csak a sebészi igény határozta meg. Betegeinknél az apnoe alatt a VV-ECMO megfelelő gázcserét biztosított. A mütéti vérvesztés a mútét típusának megfelelően alakult, a VVECMO alkalmazása nem igényelte a szívmotor technikánál megszokott teljes antikoagulációt. Első mútéteink kapcsán magasabb dózisú véralvadásgátlást alkalmaztunk, de a tapasztalat és az időközben megjelenő irodalmi közlések nyomán $[17,18]$ az antikoaguláció mértékét csökkentettük. Ezt követően az első betegek során szükséges transzfúzióigény tovább mérséklődött, 6 esetben vérpótlás nélkül végeztünk mútétet.

ECMO-kezelésnek tulajdonítható szövődményünk nem volt. A Rinieri és csoportja által vizsgált betegek 17\%-ánál volt reoperációt indikáló vérzéses szövődmény, amelynek hátterében állhatott a nagy számban mútét után is folytatott ECMO-kezelés [18]. Saját betegeinknél csak egy prolongált ECMO-kezelésre volt szükség a posztoperatív 3. napig, ezalatt vérzést nem észleltünk.

Intraoperatív halálozásunk nem volt, hasonlóan a franciaországi és az ausztriai munkacsoporthoz [11, 18, 27], míg a 30 napos perioperatív halálozás $8,33 \%(1 / 12)$ volt.

\section{Következtetés}

Összefoglalva, tanulmányunk alapján megállapíthatjuk, hogy a modern mellkassebészetben a VV-ECMO-támogatás jelentős szerepet játszik, és megfelelő indikáció esetén elsőként választandó a CPB és a VA-ECMO helyett. Technikai inoperabilitás esetén indikációja lehet az intraoperatív lélegeztetéshez használható légút vagy a gázcseréhez elegendő tüdőparenchyma hiánya a kis vérköri vérkeringés fenntartásához elegendő pulmonalis érmederrel, amennyiben nincs szükség a nagyerek reszekciójára. A VV-ECMO biztonságosan, a vérzésveszély fokozódása nélkül, több órán keresztül pótolja a teljes pulmonalis gázcserefunkciót. A VV-ECMO alkalmazása nem növelte a perioperatív morbiditást és mortalitást. A VV-ECMO bevezetésével a korábban mütéttel nem gyógyítható betegek operálhatóvá válnak. Prolongált VV-ECMO alkalmazásával a posztoperatív átmeneti légzési elégtelenség pozitív nyomású gépi lélegeztetés nélkül kezelhető, ezál- 
tal a lélegeztetéssel kapcsolatos szövődmények elkerülhetők. A fentiek alapján javasoljuk a VV-ECMO bevezetését a hazai mellkassebészeti centrumok gyakorlatába.

Anyagi támogatás: A közlemény megírása, illetve a kapcsolódó kutatómunka anyagi támogatásban nem részesült.

Szerzôi munkamegosztás: M. I.: Adatgyüjtés, a cikk megírása, ECMO-kezelés. E. J.: Adatgyưjtés, szerkesztés, ECMO-kezelés. A. L., K. Á., R.-V. F.: Irodalomkutatás, szerkesztés, a mütétek elvégzése. A cikk végleges változatát valamennyi szerző elolvasta és jóváhagyta.

Érdekeltségek: A szerzőknek nincsenek érdekeltségeik.

\section{Irodalom}

[1] Keszler P. Experiences with the simultaneous development of the Hungarian anaesthesiology, heart and lung surgery in the postwar period. [Élményeim a hazai aneszteziológia, szív- és tüdősebészet párhuzamos kialakulásáról a háborút követő időkben.] Orv Hetil. 2012; 153: 791-796. [Hungarian]

[2] Carlens E. A new flexible double-lumen catheter for bronchospirometry. J Thorac Surg. 1949; 18: 742-746.

[3] Fritzsche K, Osmers A. Anesthetic management in laryngotracheal surgery. High-frequency jet ventilation as strategy for ventilation during general anesthesia. Anaesthesist 2010; 59: 10511061.

[4] Pénzes I, Kulka F, Elek J, et al. Clinical use of high-frequency JET ventilation. [A nagyfrekvenciás JET lélegeztetés klinikai alkalmazása.] Aneszt. Int Ther. 1991; 21: 15-20. [Hungarian]

[5] Campos J, Feider A. Hypoxia during one-lung ventilation - a review and update. J Cardiothorac Vasc Anesth. 2018; 32: 23302338.

[6] de Perrot M, Fadel E, Mercier O, et al. Long-term results after carinal resection for carcinoma: does the benefit warrant the risk? J Thorac Cardiovasc Surg. 2006; 131: 81-89.

[7] Gibbon HJ Jr. Application of a mechanical heart and lung apparatus to cardiac surgery. Minn Med. 1954; 37: 171-185.

[8] Woods FM, Neptune WB, Palatchi A. Resection of the carina and main-stem bronchi with the use of extracorporeal circulation. N Engl J Med. 1961; 264: 492-494.

[9] Wiebe K, Baraki H, Macchiarini P, et al. Extended pulmonary resections of advanced thoracic malignancies with support of cardiopulmonary bypass. Eur J Cardiothorac Surg. 2006; 29: 571577 .

[10] Hasegawa S, Otake Y, Bando T, et al. Pulmonary dissemination of tumor cells after extended resection of thyroid carcinoma with cardiopulmonary bypass. J Thorac Cardiovasc Surg. 2002; 124: 635-636.

[11] Lang G, Taghavi S, Aigner C, et al. Extracorporeal membrane oxygenation support for resection of locally advanced thoracic tumors. Ann Thorac Surg. 2011; 92: 264-270.
[12] Jotoku H, Sugimoto S, Usui A, et al. Venovenous extracorporeal membrane oxygenation as an adjunct to surgery for empyema: report of a case. Surgery Today 2006; 36: 76-78.

[13] Goldman AP, Macrae DJ, Tasker RC, et al. Extracorporeal membrane oxygenation as a bridge to definitive tracheal surgery in children. J Pediatr. 1996; 128: 386-388.

[14] Abrams D, Combes A, Brodie D. Extracorporeal membrane oxygenation in cardiopulmonary disease in adults. J Am Coll Cardiol. 2014; 63: 2769-2778.

[15] ECLS registry report, international summary. Extracorporeal Life Support Organization, Ann Arbor, MI, July, 2018. Available from: https://www.elso.org/Registry/Statistics/InternationalSummary.aspx [accessed: July 12, 2018].

[16] Horita K, Itoh T, Furukawa K, et al. Carinal reconstruction under veno-venous bypass using a percutaneous cardiopulmonary bypass system. Thorac Cardiovasc Surg. 1996; 44: 46-49.

[17] Lang G, Ghanim B, Hötzenecker K, et al. Extracorporeal membrane oxygenation support for complex tracheo-bronchial procedures. Eur J Cardiothorac Surg. 2015; 47: 250-255.

[18] Rinieri P, Peillon C, Bessou JP, et al. National review of use of extracorporeal membrane oxygenation as respiratory support in thoracic surgery excluding lung transplantation. Eur J Cardiothoracic Surg. 2015; 47: 87-94.

[19] Felten ML, Michel-Cherqui M, Puyo P, et al. Extracorporeal membrane oxygenation use for mediastinal tumor resection. Ann Thorac Surg. 2010; 89: 1012.

[20] Spaggiari L, Rusca M, Carbognani P, et al. Segmentectomy on a single lung by femorofemoral cardiopulmonary bypass. Ann Thorac Surg. 1997; 64: 1519.

[21] Oey IF, Peek GJ, Firmin RK, et al. Post-pneumonectomy videoassisted thoracoscopic bullectomy using extra-corporeal membrane oxygenation. Eur J Cardiothoracic Surg. 2001; 20: 874876.

[22] Perdomo JM, Gomar C, Navarro R, et al. Use of venovenous extracorporeal membrane oxygenation to anticipate difficult one lung ventilation in thoracic surgery. J Anesth Clin Res. 2015; 6: 505.

[23] Li T, Zhang W, Zhan Q, et al. Application of extracorporeal membrane oxygenation in giant bullae resection. Ann Thorac Surg. 2015; 99: e73-e75.

[24] Redwan B, Ziegeler S, Freermann S, et al. Intraoperative venovenous extracorporeal lung support in thoracic surgery: a singlecentre experience. Interact Cardiovasc Thorac Surg. 2015; 21 : 766-772.

[25] Carretta A, Piriaco P, Bandiera A, et al. Veno-venous extracorporeal membrane oxygenation in the surgical management of post-traumatic intrathoracic tracheal transection. J Thorac Dis. 2018; 10: 7045-7051.

[26] Korvenoja P, Pitkänen O, Berg E, et al. Veno-venous extracorporeal membrane oxygenation in surgery for bronchial repair. Ann Thorac Surg. 2008; 86: 1348-1349.

[27] Rosskopfova P, Perentes J, Ris H, et al. Extracorporeal support for pulmonary resection: current indications and results. W J Surgic Oncol. 2016; 14: 25.

(Madurka Ildikó dr.,

Budapest, Ráth György u. 7-9., 1122 e-mail: madurka.ildiko@oncol.hu) 